\title{
SENTRA GERABAH DESA SELOGABUS, KEC. PARENGAN TUBAN, PILIHAN UNTUK PUNAH; PERAJINNYA BERALIH MENJADI TKW ATAU PEMBANTU RUMAH TANGGA
}

\author{
R. Bambang Gatot Soebroto \\ Departemen Arsitektur, FADP ITS \\ subrotobambang11@yahoo.com
}

\begin{abstract}
ABSTRAK
Gerabah dari desa Selobagus adalah benda yang menjadi citra mula kemajuan suatu peradapan. Permasalahannya, semakin hari perajinnya yang berasal dari kelompok ibu-ibu yang berusia telah lanjut tidak mampu memperhitungkan biaya produksi yang meliputi tenaga, bahan baku tanah liat, keahlian membuat, dan bahan bakar untuk menetapkan harga jual. Permasalahan berikutnya hampir setiap tahun tidak pernah berhasil kontinyu mendapat bantuan kegiatan PPM ITS. Akibatnya kegiatan pengembangan desa Selogabus tersebut tidak maksimal. Penghasilan, order pesanan, bantuan pengetahuan ke perajin berkurang, target-target jangka pendek, menengah, panjang tidak tercapai.

Tujuan penulisan makalah ini sebagai laporan evaluasi terbuka, supaya kegiatan Abdimas PPM ITS di kabupaten Tuban (Semen Gresik atau Pertamina). Hasil yang diharapkan, kabupaten Tuban memiliki SDM terampil, sumber bahan baku bermutu, dan ITS sebagai perguruan tinggi negeri yang diberi eran besar untuk mengembangkan dapat tercapai target-target ke depan. Tanpa peran besar ITS secara tidak langsung melakukan pembiaran, kepunahan kerajinan gerabah di pedesaan Tuban, malah beralih menjadi TKW dan Pembantu Rumah Tangga.
\end{abstract}

Kata Kunci: Gerabah/tembikar; desa Selogabus; kecamatan Parengan Tuban; TKW dan Pembantu Rumah Tangga.

\section{PENDAHULUAN}

Kerajinan gerabah di kabupaten Tuban merupakan salah satu potensi unggulan daerah tersebut. Kabupaten Tuban juga memiliki sumber-sumber bahan baku untuk pembuatan gerabah (keramik), yakni tanah liat, pasir kwarsa, kapur juga pewarna alam (semacam tanah;"puru"). Kabupaten Tuban memiliki tiga sentra gerabah; Sentra gerabah kecamatan dan desa Semanding, sentra gerabah desa Ngadirejo, kecamatan Rengel dan desa Selogabus, kecamatan Parengan.

Produk gerabah buatan desa Semanding sebagian besar adalah 'empluk' (semacam mangkuk bundar diameter 15-18 cm) untuk pengawetan ikan asap. Teknik pembuatannya memakai alat; meja putar bilah datar, memakai tenaga penggerak, tangan. Beberapa ibu-ibu membuat memakai teknik pukul. Tangan kiri memegang batu bundar, berada di bagian dalam gerabah, sedangkan tangan kanannya memukul-mukul memakai sebilah kayu keras. Dinding gerabah yang dipukul-pukul permukaan bodinya akan menipis hingga gerabah tersebut memiliki dinding bodi gerabah yang berketebalan ketipisan yang sama. Gerabah yang memiliki dinding bodinya tidak merata (tipis-tebal) akan berakibat ketegangan yang berbeda ketika akan di keringkan serta dibakar. Berakibat gerabah tersebut retak atau pecah. Sehubungan desa Semanding berdekatan dengan potensi perikanan laut kabupaten Tuban, tidak terlalu sulit untuk memasarkan barang gerabah yang berhubungan dengan hasil laut.

Desa Ngadirejo kecamatan Rengel berada di tepi sungai Bengawan Solo (sungai yang setiap tahun Januari, Februari dan Maret melimpahkan airnya membanjiri desa-desa yang dilewatinya, termasuk desa Ngadirejo ini). Perajin sentra gerabah ini buatannya rata-rata berukuran besar coek, 
wajan gerabah, padasan (tempat ber wudlu), guci, pot kembang dan lain sebagainya). Teknik pembu (teknik primitive) atan dengan cara di pukul-pukul. Tagan kiri memegang batu bundar menahan dari sebelah dalam bodi gerabah dan tangan kanan memukul-mukul dari permukaan sebelah luar memakai sebilah papan kayu yang keras. Tujuan dipukul-pukul ini untuk menipiskan bodi gerabah agar sama ketebalannya, supaya ketika pengeringan dan pembakaran tidak retak atau pecah. Tempat pembakaran gerabahnya di tegalan terbuka; gerabah-gerabah mentah yang akan dibakar di timbun di tengah tegalan memakai damen (limbah padi) dan kayu bakar. Kelemahan teknik pembakaran di tegalan terbuka demikian, suhu panas pembakaran tidak memusat membakar gerabah, sebagian terbuang ke udara luar. Akibatnya panas yang tidak merata, gerabah-gerabah yang dibakar sebagian retak atau pecah (lebih kurang 30-40 \%). Proses pemasarannya di bawa ke pasar memakai sepeda. Melihat keadaan demikian penulis dibiayai oleh PPM ITS melakukan kegiatan pengabdian. Desa Ngadirejo ini diberi sebuah tungku sepanjang tiga mater (disebut 'tungku sorong') sebab membakar benda gerabah memakai teknik di sorong-sorong; masuk keadaan mentah, ditengah pada pusat semburan api membara dan pada bagian ujung keluar telah matang. Lebih kurang per 7-10 menit telah matang dan keluar. Tetapi tidak bertahan lama (tidak sampai 2 tahun) tungku tersebut dihancurkan penduduk yang memiliki lahan. Tungku tersebut memang khusus untuk membakar gerabah-gerabah berukuran kecil, yang dibuat memakai putaran meja putar atau cetakan. Diberi ke penduduk desa dengan maksud supaya mereka perlahan beralih membuat gerabah-gerabah berukuran kecil, agar mudah dibawa ke pasar, dibandingkan membawa gerabah-gerabah yang berukuran besar-besar.

Sentra gerabah ke tiga adalah di desa Selogabus kecamatan Parengan Tuban. Desa yang berdekatan dengan kabupaten Bojonegoro dan ditengahnya dilewati anak sungai Bengawan Solo; yakni Sungai Kening. Sentra yang hampir punah, sebab dari tahun 2000, ibu-ibu perajinnya masih sekitar 20 orang, sekarang maksimal tinggal tiga orang ditambah satu orang perajin laki-laki (pak Sadar namnya). Perajin laki ini memiliki minat besar untuk belajar kerajinan gerabah sehingga cukup sering dikirim belajar ke berbagai instansi maupun perguruan tinggi yang memiliki jurusan keramik. Ibu-ibu di desa selogabus ini semula membuat kendi dan celengan. Membuat kendi ternyata memakai tahap yang panjang; sejak dari bahan tanah yang perlu disaring, di endapkan, dibuat memakai tiga bagian; perut kendi, leher berikut kepala dan corot, tempat mengeluarkan air. Setelah dibiarkan beberapa saat, ketiga bagian kendi tersebut disatukan. Selanjutnya tahap pengerasan yakni dengan diangin-anginkan di dalam ruangan selama kira-kira 1-2 hari. Setelah cukup keras kendi memasuki tahap meng 'osek' yakni menggosok permukaan luar kendi memakai batu licin (semacam akik, sebutan mereka 'batu bintang') separuh bodi keatas hingga kepala kendi digosok vertical, kemudian separuh perut kendi keatas di gosok mengikuti putaran meja putar. Tujuan digosok demikian serupa dengan perajin desa Ngadirejo kecamatan Rengel memukul-mukul permukaan bodi gerabah. Mempersempit pori-pori, hanya memakai pukulan juga untuk menipiskan bodi gerabah. Sedangkan di osek tujuannya hanya memperkecil poripori permukaan kendi, agar air tidak cepat merembes keluar. Tetapi hanya terhenti di batas tepi dinding bodi kendi. Air tersebut terhembus angin dari luar menyebabkan air kendi tersebut segar dan dingin. Sayangnya perajin desa Selogabus sekarang mulai enggan memproduksi kendi, disebabkan tahapannya yang panjang dan rumit. Selain itu harganya murah hanya sekitar Rp.2000-Rp.5000/ buah. Harga demikian rendahnya akibat; dipermainkan penjual yang datang ke desa tersebut. Selain itu sebagian besar perajin tidak mampu baca, tulis dan hitung. Mereka tidak mampu menetapkan berapa harga yang pantas dari sebuah kendi, biaya tenaga, bahan, transport hingga biaya membakar. Kemudian perajin berangsur beralih membuat gerabah-gerabah berukuran kecil (mainan anak; anglo, kendi, cowek, ulegan berukuran kecil, segenggaman tangan). Perobahan inipun tidak terlalu menolong, perajinpun tidak mampu menentukan harga, bahkan seringkali mereka menentukan harga berbeda-beda sekalipun pesanan gerabahnya tipenya sama. 
Keistimewaan sentra gerabah desa ini adalah buatannya sangat halus dan tipis (dinding bodi kendi setebal 2,5-3 mm) (menandakan mereka adalah perajin yang handal). Ibu-ibu perajinnya membuat memakai teknik yang sangat unik; memutar gerabahnya dengan cara di sepak-sepak; bilah mejanya posisi miring, demikian juga gerabahnya. Leher meja putarnya dibelit tali yang ujung tengahnya terhubung batang kayu terikat pada ujung busur bambu, sedangkan ujung tali lainnya terhubung papan kayu buat pijakan sepakan kaki. Teknik yang langka ini hanya dikuasai ibu-ibu perajin tua di desa Selogabus, kecamatan Parengan itu. Diluar sentra tersebut tidak ada yang mampu. Selain tiga perajin ibu-ibu itu ada satu perajin lelaki (pak Sadar) yang menikahi salah satu perajin di desa itu. Gerabah buatan pak Sadar berukuran besar-besar dan beraneka ragam. Karena daya tarik sentra gerabah tersebut dipilih penulis untuk menerima bantuan sebuah tungku berukuran besar (satu meter kubik) dibangun di lahan milik Pak Sadar (tahun 2000 dana dari Balitbangda Profinsi bersama ITS). Tungku pembakaran tersebut mampu membakar hingga suhu tinggi (berglasir). Diperuntukan semua perajin di desa itu, akantetapi ibu-ibu perajin desa itu enggan memakainya, lebih memilih membakar di tegalan terbuka.

Sekarang kerajinan gerabah di desa-desa khususnya di desa Selogabus kecamatan Parengan tersebut mulai surut. Datangnya TKW atau PRT dari Jakarta pada hari raya Lebaran,ke desa membawa uang, kemewahan dan gaya hidup baru. Rumah-rumah dari bahan anyaman bambu (gedek/sesek) berganti memakai dinding bata, berpilar dan lantai rumahnya licin dikeramik. Hal ini menggoga para remaja putus sekolah untuk mengikuti jejak teman-temannya yang lebih dahulu menjadi TKW atau PRT. Keterampilan kerajinan pembuatan gerabah yang memerlukan keterampilan, latihan yang panjang, tetapi hasilnya tidak seberapa, menjadi hal yang tidak menarik. Mereka lebih memilih yang simpel, tidak perlu kotor-kotor memegang tanah, tidak perlu belajar keterampilan membuat gerabah yang susah, tinggal berangkat, sudah bisa melihat ibu kota Metropolitan dan mendapat gaji besar. Hal inilah menjadi target untuk diupayakan di kurangi.

\subsection{Permasalahan}

Membuat gerabah (kendi) rumit dan tahapannya panjang, perlu belajar lama terus menerus. Mau mengolah tanah liat yang kotor, harga tiap gerabah murah dan jualnya relative sulit. Terdapat peluang-peluang untuk menjadi TKW (dari para penyalur yang mencari ke desa-desa, baik yang legal maupun yang illegal). Selain itu bantuan-bantuan dari pemerintah, program bantuan teknik maupun penyuluhan dari kabupaten tidak musti setiap tahun ada. Kegiatan Abdimas dari penulis melalui program pengabdian dan penelitian PPM ITS jarang didapat (padahal setiap tahun rutin mengajukan proposal). Membuat target-target jangka pendek, menengah dan panjang. Bahkan penulis membuat 'pohon kegiatan' sejak tahun 2000 sebagai panduan proposal kegiatan berkelanjutan-kesinambungan, tetapi proposal juga tidak mudah diterima. Akibatnya program abdimas untuk desa-desa tidak segera tercapai, menjadi 'molor' berkepanjangan. Perajin di desa berulang terhenti bahkan ada yang sudah menutup kegiatan kerajinan gerabah. Sungguh ironi sekali, penulis sebagai kepanjangan dari ITS melihat keadaan tersebut merasakan seolah ITS mengabaikan kesulitan-kesulitan di desa.

\subsection{Tujuan}

Sebagai evaluasi terbuka kepada ITS khususnya PPM, supaya menjadi perhatian pertimbangan penerimaan proposal dengan melihat program-program jangka pendek, menengah dan panjang yang sejak tahun 2000. Selain itu juga capaian keberhasilan target yang telah diupayakan setiap selesai laporan PPM sebelumnya.

Tujuan berikutnya tetap menyiapkan proposal sebaik-baiknya, sebab bila tidak diterima, setahun para perajin di pedesaan tidak ada yang peduli dan membantu. Ketidakhadiran kita sebagai 
'kepanjangan' dari ITS berarti sama dengan minusnya bantuan teknik, arahan penyuluhan dan datangnya order atau uang.

\subsection{Manfaat}

Apabila kegiatan Abdimas berlanjut terus setiap tahun, pendanaan dari ITS maupun penyandang dana lainnya (Perindustrian, Balitbangda, maupun BUMN yang berkaitan dengan kabupaten Tuban) target-target dari pohon pengabdian bisa diharapkan tercapai. Intinya perajin menjadi banyak, perajin tua terus berproduksi dan desa menjadi makmur bukan karena banyak TKW dan PRT nya tetapi mandiri, hidup dari kerajinan gerabah yang telah lama dikuasai dari turun temurun.

\subsection{Relevansi}

Penulis lulusan (S1) Seni Rupa (spesialisasi Seni Keramik), sejak tahun 1989 sudah melakukan kegiatan Penelitian dan Pengabdian Masyarakat di kabupaten Tuban; di desa Ngadirejo kecamatan Rengel dan desa Selogabus, kecamatan Parengan. Beberapa alat yang telah diberikan buat para perajin; meja putar, alat cetak, tungku pembakaran keramik serta teknik-teknik pengerjaan modernisasi pembuatan gerabah serta pemasaran online, menitipkan di counter Batik Keris di kota Surabaya dan Bali.

\section{TINJAUAN PUSTAKA}

Dalam Tinjauan Pustaka kali ini akan memperlihatkan beberapa kutipan meliputi; Tanah Liat dan Pengolahannya, Teknik memutar tanah liat memakai meja putar Kualitas dinding bodi keramik yang ideal.

\subsection{Tanah Liat dan Pengolahannya}

"Clay is e simple material. It is abundant, cheep, easily acquired and prepared, and it does not require extensive processing, as do most of the raw materials which we use for making things. If this were not so, it would have been impossible for primitive people to make pottery. Pottery can still be made whitout resort to science.

Clay is also temperamental material. Its plasticity or workability varies widely, so that some clays which serve quite well for one things are useless for another. Clay shrinks when it dries and shrinks more when fired, and this creates all sorts of problems in making pottery. The reactions of clay to the fire may seem unpredictable and even under the most carefully controlled conditions a certain amount of uncertainty attends the firing process". (Rhodes, 1957).

\section{Preparing clay flour}

If you buy your clay in plastic form, it won "t need any preparation, but you may prefer to buy it dry. It is usually cheaper this way (the price per pound may be the same but you do not pay for water), and it is easier to store until ready for use. Also, if you plant make any special clay bodies for which the ingredients must be weighed out, you will have to have your clay in dry form. Clay flour may be prepared for use by spreading a layer about $1 / 2$ " thick on the bottom of a crock or pail, then sprinkling it with water until it is thoroughly moist but not soaking wet. Another layer is then spread on top of the first and sprinkled, the process continuing until the crock is full. After an hour or two, the clay will be ready for wedging.

If the clay you buy dry is not in flour form but comes in lumps, it will be necessary to make a slip out of it. Slip is clay in liquid form. 


\section{Wedging}

Before clay is used, it must be wedged. This is the oldest method known for getting clay into good working condition, and it is still the best. Wedging makes clay uniform in texture throughout and gets rid of air pockets. If your clay is too dry, you can moisten it during the wedging process; if it is too wet, wedging will dry it.

You will need a wedging board in your studio. This is havy slab of plaster with an upright to hold a taut wire and a turnbuckle or some other device to keep the wire tight. Thewedging board will receive a lot of rough usage so it should be as solidly constructed as you can make it.(Kenny, 1949)

\subsection{Teknik Memutar Tanah Liat Memakai Meja Putar}

"Throwing on Potter"s Wheel, Throwing on a potter"s wheel is the most advanced way to make pottery by hand. Throwing is the process of making pottery by shaping a ball of clay by pressure of the hands while the clay turns on a wheel. Of all the methods of making pottery, throwing offers the greatest possibility for the spontaneous creation of a piece. It is also the most fun when mastered. You can get results from it in much less time than by building with coils or slabs". (Roy, 1959).

\section{CENTERING CLAY}

"It is important to "centre" the clay on the wheel before throwing. Clay that is off-centre is difficult to control as the wheel exerts an outward force when revolving. It will also produce a pot that is uneven in shape or with walls that vary in thickness, resulting in weak areas. While checking that the clay is centred that potter squeezes the clay up into a cone and down again. This ensures that any tiny air bubbles are worked out of the clay".

The clay must be of an even consistency, well wedged and kneaded, but not too soft or it will be difficult to throw. Experience and practice will soon let you know when the clay feels right. While centring and throwing keep the clay and your hands moist. Try not to overwork the clay or make it too wet as it will lose its plasticity. (Christy, G and Pearce, 1992).

\section{CENTERING AND OPENING UP}

The clay must be evenly mixed bring before centring is commenced. Centring needs to be done quickly and firmly. It is a skill which requires good personal tuition to develop a sound technique. Once you have opened up the form, begin to thin the clay against the outward thrust of the revolving wheel.

\section{Point to remember}

* If the clay is too soft it will not expand and hold its shape, and if too stiff the pressure needed to thin the walls will strain the pot and it will become twisted.

* Success lies in judging the exact degree of pressure needed on both the inside and outside of the pot.

* If the clay is worked for too long it becomes tired and will not expand easily.(Clark, 1983)

\subsection{Kualitas Dinding Bodi Yang deal The finished cylinder}

Let's see what you have accomplished. Measure the height of the cylinder. Were you able to raise it to six inches? Good! Eight inches? Excellent! More than eight? You"re an old hand ought not to be reading this chapter at all. 
Now put your knife on the top edge and cut straight down to the bottom, then do the same thing on the opposite side.

Cut Through the base and remove one- half of the cylinder, so that you can look at the cross section ( it will take courage to do this, but remember this cylinder was practice- you did not intend to keep it anyway) Is the wall even in thickness, only slightly heavier at the bottom? Is it free from thin spots? This inspection will tell you what to work for next time.

Don't be discouraged by your first results. Throwing on the wheel sounds a lot simpler than it is. The ease with whice a potter does it is highly deceptive, but as you practice, your skill will increase. Don "t save any of until you are able to make one 9 " high, with walls no thicker than $3 / 8$ " throughout. (Kenny, 1949)

\section{GLASSING POTTERY}

\section{An Introduction to Glazing}

Each type glaze is made and used in a different manner. A glaze is made up of least three different kinds of subtances in powder form: (1) silica melts to form to glasslike glaze; (2)alumina prevents the glaze from running of the ware in firing; and (3) lead or calcium oxide lowers the melting point of silica and fits it to the body.

These ingredients are thoroughly ground in proper proportion, mixed with water, and applied to the ware. The glaze melts when heated to a definite temperature and flows like a liquid. It unites with the clay of the vase. The glaze forms a smooth coating of glass or enamel on the surface as it cools and makes the vase waterproof. Glaze also adds color.

\section{THE FIRING PROCESS}

\section{Kiln and firing}

A potter without a kiln (pronounced kill) would be like a baker without an oven. Clay must be fired just as dough must be baked. If an unfired piece were filled with water, it would soon be a lump of clay again. If an unfired piece of pottery were given a sudden bump or were handled carelessly, it would break. It must be made waterproof and permanent. This is done by placing the piece in an intence heat. The heat drives out any remaining moisture and fuses (vitrifies)the clay coils or pieces.

The clay changes from its original nature into durable, stonelike body. All the particles of clay unite and fuse so closely together that they form a single mass. If there are any defects, they will show up during or after firing. A poor piece should not be fired. It is better to break it up and reuse the clay.

\section{Muffle Kiln}

The muffle kiln is metal case shaped like a box or barrel.It is lined with fire brick (refractory), Which stands high temperatures and serves as insulation. The muffle kiln has flues all aroud the edge of the interior. The flames and fumes from the fire below pass through these flues to the chimney above so that they do not come in contact with the pottery itself.

\section{Open Kiln}

The open kiln has no flues and may use either electricity, oil, or gas as fuel. When oil or gas is used, the pottery is placed inside saggers. These are boxlike refractory containers that fit one on top of another. The flames thus strike the saggers, but not the pottery.

There is usually one peephole in the front of an open kiln through which the progress of the firing may be watched. The heating elements of most electric kilns are around the sides and at the bottom. 


\section{Using the Kiln Safely Coutions about Heat}

1. If leaks are suspected, get the right person to make the proper checkup immediately.

2. Be sure that there are no leaks of any kind. Gas, oil, and electricity are servants- when under control. Leaks let them get out of control.

Since gas cannot be seen, use a flashlight when looking or smelling for the source of a leak. Do not use a match.

Oil leaks usually can be seen or left. Loose electrical conections should be tightened, and frayed wires replaced.

3. Keep the chimney flues on oil and gas kilns partly open to permit poisonous fumes and escape.

4. Watch pipes to chimneys to see that they do not become loose, rusted, or overheated.

5. Turn off heat immediately if no one is available to attend to the difficulty.

6. Remove any possible fire hazard by close inspection for lakes.

7. Never leave the kiln unattended for any length of time.

\section{Coutions about cold}

1. Never open the kiln while it is being fired. The inrush of cold air can cause damage or breakage. The fragment caused by the sudden chilling of both the heated articles and the kiln interior may even fly out and hurt you.

2. Allow the kiln to cool slowly, and open it gradually, A general rule is that the kiln should take at least twice as long to cool as to fire.

3. Test the ware by touching it cautiously after the kiln has cooled thoroughly. Remove, or draw, the were only when it is cool enough to handle with your bare hands.

\section{Pyrometer ang Pyrometric Cones}

Temperature in a kiln is determined by the use of a pyrometer or pyrometric cones. The pyrometer has two parts (1) a sensitive electric meter, and (2) a thermocouple to carry the current from the kiln to the meter. The thermocouple is made of two unlike wires, alumel and chromel, which generate a slight electric current when heated. The cones are small pyramids of china clay, feldspar, and flint. They soften, bend, and melt at different temperatures. Their bending depeneds upon the length of time or speed of firing. The cones are numbered $05,04,03,02$, etc. When the temperature in the kiln reaches 1915 degrees Fahrenheit in about 8 hours, the Orton cone marked 05 should bend over. It would not bend if 1915 dgrees were reached in 4 hours, for faster firing raises the cone's melting point to 1940 degrees. When the temperature gets 35 degrees hotter, the 04 bends, and at 2014 degrees the 03 bends.

Place three of these cones at a slight angle (10 dgrees) in a base or pat of clay. The middle cone is for the temperature desired: the others record higher and lower temperatures. Put these groups of three cones in different parts of the kiln (top and bottom as well as front and back) to find any temperature variations. Set one group of cones so that it may be seen through a peephole.

\section{FIRING CHART}

\begin{tabular}{|c|c|c|c|c|}
\hline No. & $\begin{array}{l}\text { Orton } \\
\text { Cone No. }\end{array}$ & $\begin{array}{l}\text { Fahrenheit } \\
\text { temperature }\end{array}$ & $\begin{array}{l}\text { Kiln } \\
\text { color }\end{array}$ & Fire \\
\hline 1. & 15 & 2610 & Buish white & Porcelain \\
\hline 2. & 10 & $2385\}$ & Light yellow & Stonewere \\
\hline
\end{tabular}




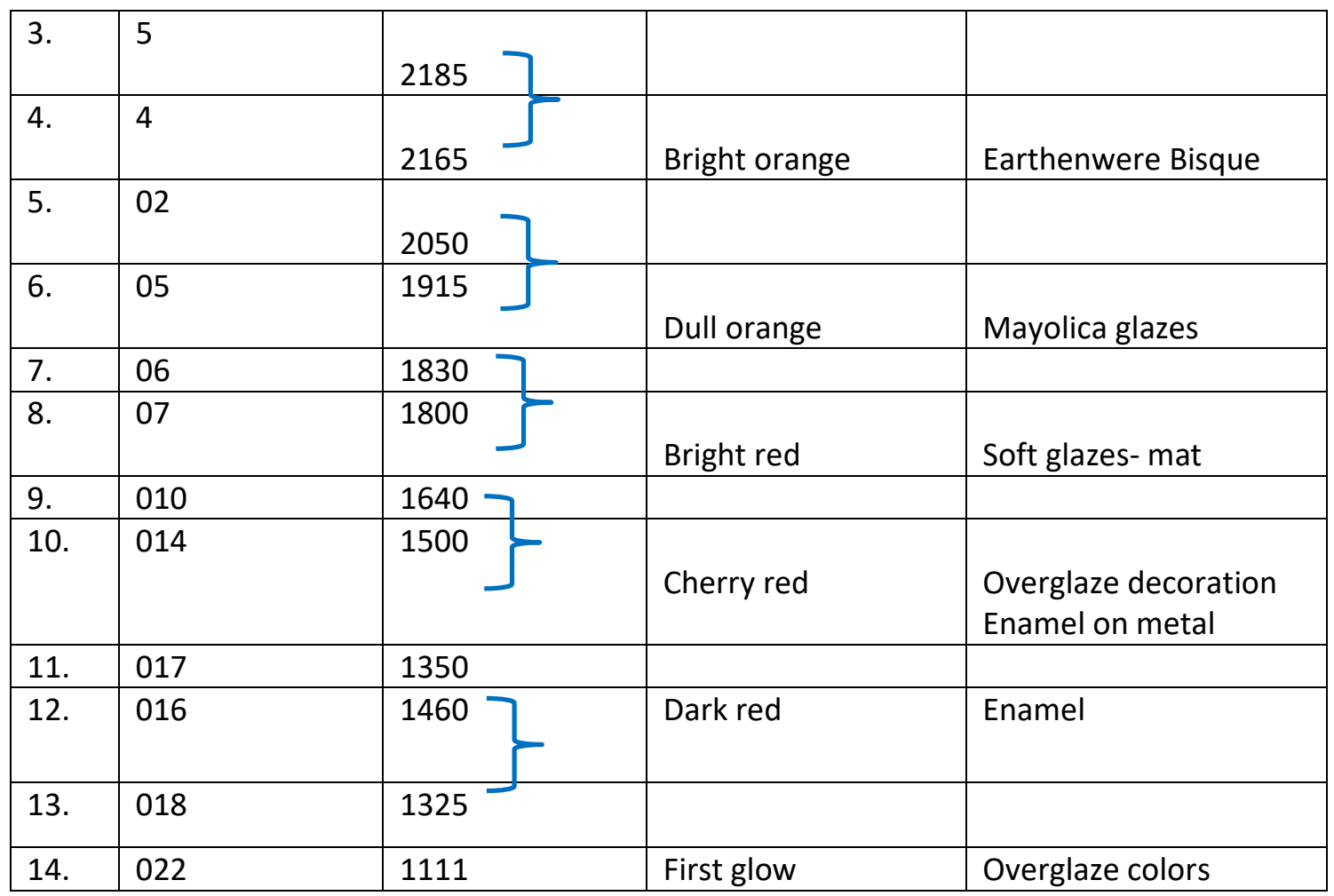

\section{BISQUE OR BISCUIT- WARE FIRING}

After a gas or oil muffle kiln a stacked and the cones arranged, the flues at the open end are put into place.The cracks at the bases of the flues are filled with soft clay to prevent the escape of fumes and flames.

1. If you are using oil or gas, open all the dampers and start the fire. For an electric kiln, turn on the switch.

2. Leave the door slightly open onany type of kiln for about $1 / 2$ hour. This allows damp air to escape.

3. Increase the heat slowly until 1000 degrees Fahrenheit is reached. Then advance it faster in order to reach to the maximum heat in about 3 or 4 hours. By this time the kiln should be dull red inside. If using oil or gas, reserve some extra pressure to be used to ward the and of the firing. In an electric kiln, advance the switches from low to medium to high at about 1- to 2hour intervals. Become chiled.

4. In approximately 5 to 8 hours, the lower 05 cone should begin to bend. This depends upon the kiln and the fuel being used. This depends upon the kiln and the fuel being used. Also, the heavier the load of pottery is in the kiln, the longer the time before the cone bends. From then on it will be well to watch the progress of the firing more closely, both through a peephole and on the pyrometer.

5. When the middle 04 cone has bent over completely, shut off the heat. If there are dampers at the top, close them. Experience will help you decide exactly when the heat should be shut off 
and what to do about dampers.

An automatic shutoff, especially on an electric kiln, is well worth its extra cost.

6. Allow the kiln to cool to below 300 degrees Fahrenheit. This may take 15 to 20 hours. Open the door and dampers (if the kiln has them) very slowly so that the ware does not become chilled. Chilling my create tensionsor cracks, and in glazed ware, crazing. Lessen the temptation to open the kiln too soon by planning the firing so that cooling takes place at night.

Note the shrinkage of the pieces.

\section{Opening the kiln}

The most anxious and fascinating time of the whole pottery operation comes when you open the kiln. These are moments of both surprise and disappointment, and both emotions may be the result of a single firing. One glaze that was tried just for luck may come out beautifully, and another that was thought sure satisfy may not.

1. Let the kiln and the ware in it cool to below 300 degrees Fahrenheit.

2. Open the kiln slowly and carefully. See "Bisgue or Biscuitware Firing".

3. Remove any stilts which stick to the bottom of the ware by carefully prying them loose with a file, cold chisel, or pliers.

4. Remove any glaze from the bottom of the ware with a file or on a grinding wheel. (Roy, 1959)

\section{Forming a Piece on the Jigger}

To form a piece on the jigger means to use a plaster mold that turns on a wheel. The other half of a jiggering rig is a hinged arm that has a metal template fastened to it. This cuts the clay. The mold may be used either for the outside or inside contour. The template forms the opposite contour in each case.

\section{Jiggering an Outside Piece.}

1. Roll out a slab of clay to about $3 / 8$ or $1 / 2$ inch thickness.

2. Lay it over the plaster mold which forms the inside of the plate.

3. Pull the template down to shape the bottom of the plate and make the bottom the right thikness. This is $3 / 16$ inch, if grog has been added.

4. Allow the clay to dry until it can be removed and finished. (Ror, Vincent, 1959)

\section{METODE}

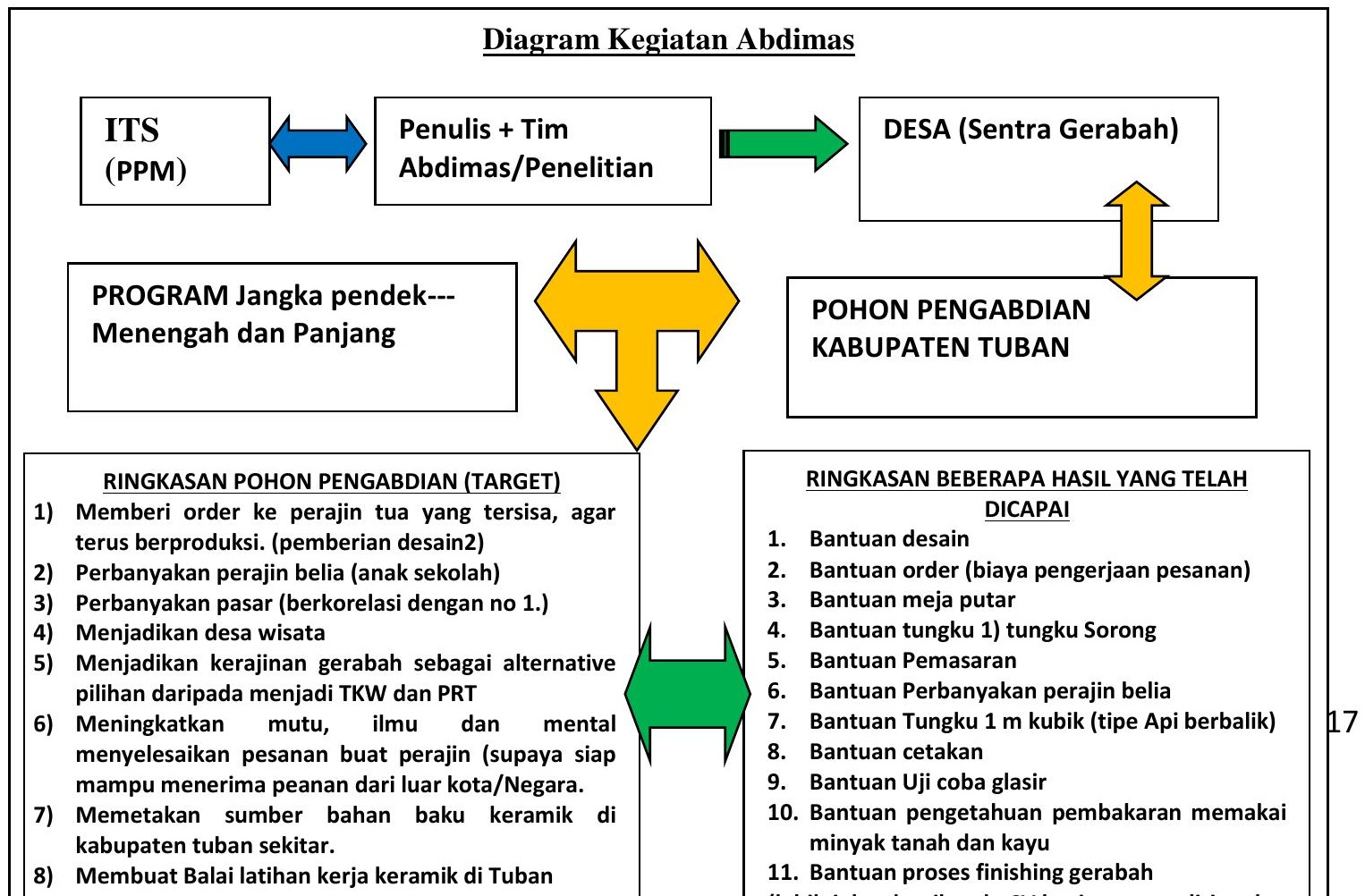


Metode pemberian order kepada perajin tua, desa Selogabus kecamatan Parengan.

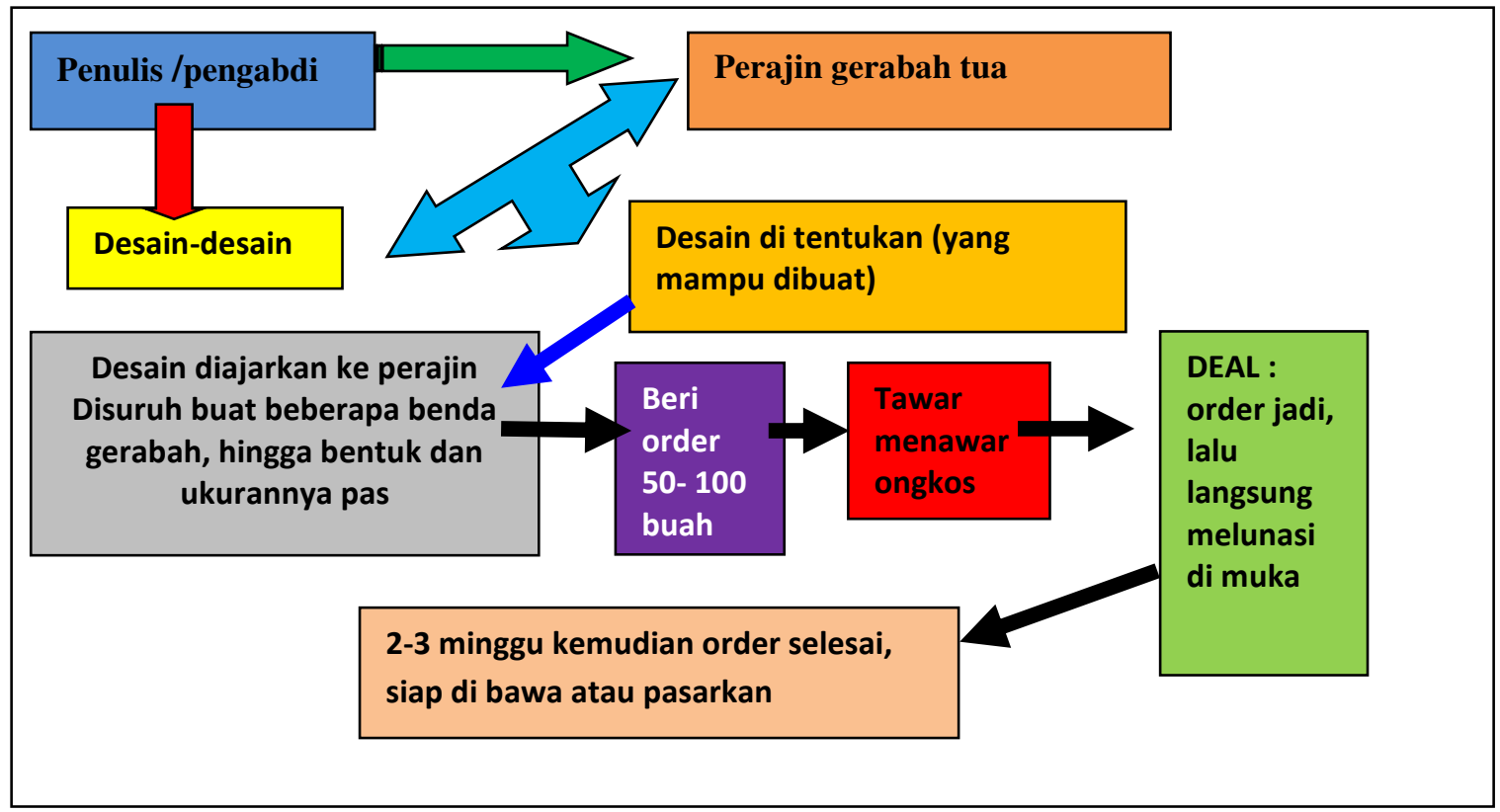

\section{ANALISIS DAN PEMBAHASAN}

\subsection{Kerajinan Gerabah Desa Selogabus Kecamatan Parengan Tuban}

Gerabah buatan sentra desa ini adalah sentra gerabah yang terbaik dibandingkan sentra gerabah lainnya di Tuban (Semanding dan Ngadirejo kecamatan Rengel). Macam benda yang dibuat (kendi, celengan dan cenderamata-mainan anak-anak; cowek, anglo, wajan mini), teknik pemakaian alat yang unik (meja putar miring dan di putar memakai tenaga sepakan kaki). Selain ibu-ibu perajin masih ada satu orang perajin laki-laki; pak Sadar. Gerabah buatan pak Sadar berukuran besar-besar beraneka macam, hingga pernah membuat ukuran satu meter. Pak Sadar memiliki minat kepada kerajinan gerabah, oleh sebab itu sering di kirim-kirim oleh perindustrian ke berbagai tempat dan instansi yang memiliki bidang pelatihan, jurusan keramik. Oleh sebab itu pak Sadar membuat memakai pengetahuanpengetahuan dari kursus-kursusnya, termasuk proses finishing benda gerabahnya. Alat yang dikuasai pak Sadar adalah meja putar datar, memakai tenaga putar tangan. Di desa Selogabus ini mendapat bantuan sebuah tungku pembakaran keramik tipe "api tidak langsung atau berbalik" seluas satu meter kubik. (desain rancangan penulis) bantuan dari Balitbangda profinsi dan ITS (tahun 2000) diperuntukan semua perajin desa boleh memakainya, sekalipun dibangun di tanah miliki pak Sadar. Selain itu pak 
Sadar sendiri sudah memiliki tungku pembakaran sendiri tipe 'api langsung'. Sejak penulis datang melakukan Abdimas di desa itu (1989), jumlah perajin 20 orang lebih, sekarang tahun 2018 susut terus hingga tinggal tiga orang +1 orang lelaki; (pak Sadar).

\subsection{Perajin Tua dan Perbanyakan Perajin Belia}

Ibu-ibu perajin tua sejak tahun 2000 masih berkisar 20 orang lebih, sekarang tahun 2018 ibu-ibu perajin tinggal 3 orang saja. Hal ini sangat ironi sekali, disebabkan beberapa hal;

- keterbatasan pendidikan, sehingga tidak mampu menghitung; berapa harga yang harus ditetapkan, berapa harga tenaga, biaya bahan baku hingga bahan bakar kayu. Sehingga membuat gerabah yang prosesnya relatif panjang dan bertahap tidak diimbangi dengan harga jual per gerabah.

- Para pedagang membeli gerabah buatan desa Selogabus sesukanya menawar. Sehingga perajin yang tidak mampu berhitung menjadi tidak menghargai kerajinan gerabah yang telah lama ditekuni. Harga gerabah yang ditetapkan menjadi murah.

- Selain itu datangnya para TKW dan PRT pada hari raya Lebaran ke desa (membawa kekayaan, kemewahan dan uang lalu membangun rumah-rumah mereka) serta para agen pencari tenaga kerja kedesa-desa sudah sangat menggoda para remaja putus sekolah. Akhirnya tidak ada lagi yang berminat mempertahankan kerajinan pembuatan gerabah di desa itu.

\subsection{Gerabah Buatan Desa Selogabus Kecamatan Parengan Tuban}

Sentra kerajinan gerabah desa Selogabus kecamatan Parengan Tuban semula penghasil kendi dan celengan. Membuat kendi ternyata tidak mudah, bahkan rumit, diperlukan bahan baku tanah liat (lempung) yang di saring;

- Tanah saringan di siapkan membuat kendi,

- Kendi dibuat dalam tiga bagian; bagian perut kendi, leher berikut kepala kendi dan corot tempat mengeluarkan air.

- Setelah di angin-anginkan, kendi cukup kuat, bagian-bagian tersebut disatukan. Kemudian dianginanginkan lagi didalam ruangan beberapa hari dan dibolak-balik agar bagian alasnya kering.

- Selum kering betul bodi kendi di gosok ('Osek') memakai batu semacam akik bening ('batu binatang' menurut perajin desa Selogabus). Tujuannya supaya permukaan bodi pori-pori kendi menyempit, sehingga air tidak mudah merembes keluar.

- Setelah tahap osek, selanjutnya di angin-anginkan kembali di dalam ruangan. Alasannya supaya terjadi pengeringan perlahan, apabila di jemur akan terjadi pengeringan permukaan tetapi bagian dalam belum mongering, akibatnya terjadi retak bahkan pecah.

- Sebelum di bakar masih perlu dijemur di tegalan terbuka setengah hari, agar kering betul.

Sekarang pembuatan kendi sudah mulai di tinggalkan, berganti membuat mainan anak-anak (cowek, wajan, anglo, ukuran mini), kemudian penulis mengarahkan membuat cenderamata pernikahan seukuran sama dengan mainan anak-anak yang mereka buat; seperti, tempat lilin, vas mungil, asbak, tempat tusuk gigi, lilin aromaterapi, atau kendi mungil.

\subsection{Desain-Desain Baru}

Desain- desain apapun tetap harus di sesuaikan dengan kemampuan yang dipunyai para perajin; keterampilan yang dikuasai ibu-ibu perajin yang mampu membuat gerabah dengan cara di sepak-sepak dan memakai alat putar miring. Selain ibu-ibu perajin ada juga perajin lelaki satu-satunya (pak Sadar namanya) yang berbeda cara membuatnya; memakai alat putar posisi datar, tenaga tangan. Beberapa kali pak Sadar diberi desain-desain, tetapi tidak jarang dia juga membuat aneka macam bentuk gerabah hias; aneka guci, hiasan dinding, berbagai bentuk vas bunga dan lain sebagainya. 


\subsection{Problematika Mendasar Perajin (Harga Gerabah Yang Rendah)}

Problematika perajin gerabah desa Selogabus, pertama adalah keterbatasan pendidikan sehingga tidak mampu menetapkan harga gerabah. Berapa biaya yang harus dikeluarkan untuk ongkos tenaga, bahan baku, bahan bakar hingga biaya finishing agar lebih menarik.

Akibatnya harga jual berubah-rubah, hal ini menarik pembeli (pedagang) untuk mempermainkan harga. Justru harga yang rendah membuat gerabah (kendi) tidak memiliki nilai, akhirnya pendapatan perajinpun rendah sehingga membuat kendi yang rumit dan proses panjang menjadi berkesan sia-sia.

\subsection{Datangnya TKW Dan PRT yang Menggoda}

Para pekerja TKW dan PRT setiap hari raya Lebaran pulang kampong membawa uang, kemewahan dan membangun rumah-rumah mereka, Selain itu juga datangnya angen-angen pencari pekerja ke luar negeri. Atas nama mencari peruntungan atau memperbaiki nasib, memberi harapan kepada remaja putus sekolah yag lama merasakan kemiskinan.

\subsection{Upaya-Upaya}

Bantuan-bantuan yang telah dilakukan oleh penulis dan tim, pada intinya desain-desain, teknik pembuatan, teknik pembakaran, teknik finishing. Alat kerja; meja putar, kompor minyak hingga teknik membakar tungku khusus, Tungku sorong, tungku tipe api berbalik serta cara membuat cetakan. Upaya sebagai gambaran program telah disusun kedalam program-program jangka pendek, menengah dan jangka panjang.

\subsection{Harapan}

Sentra kerajinan gerabah desa Selogabus kecamatan Parengan Tuban tidak punah, sebab segera dilakukan upaya-upaya serentak berbagai pihak. Bagaimanapun kegiatan Abdimas musti berbuah keberhasilan, tetapi apabila tidak di dukung pendanaan yang kontinyu akan berlarut-larut panjang. Program yang terencana hanya akan menjadi cita-cita. Dukungan pertama; adalah PPM ITS mempermudah penerimaan proposal yang berkelanjutan, kedua; perindustrian kabupaten Tuban, ke tiga adalah penyandang dana lainnya (seperti Semen Gresik, Pertamina dan lainnya).

\section{SIMPULAN DAN SARAN}

Kegiatan Abdimas adalah program kegiatan PPM dari Institut Teknologi Sepuluh Nopember Surabaya dimana seluruh dosen mendapatkan kesempatan untuk menerima pendanaan. Adapun kabupaten Tuban adalah daerah yang di'titip' kan ke ITS untuk dapat dibantu dan kembangkan dengan segala upaya kegiatannya baik Abdimas maupun Penelitian. Sentra gerabah Tuban adalah daerah pilihan yang bisa penulis bantu untuk kembangkan. Karena latar belakang adalah dosen ITS seyogyanya ITS memberi kemudahan kepada penulis atau siapa saja untuk melakukan kegiatan Abdimas atau penelitian. Sehingga tujuan utama pengembangan masyarakat Tuban tidaklah percuma. Dukungan instansi sebesar ITS merupakan citra besar perhatian bahwa ITS memiliki peran membantu pedesaan (khususnya kabupaten Tuban). Tanpa bantuan dari instansi utama, pohon rencana Abdimas hanyalah cita-cita kosong. Cita cita dapat tercapai apabila didukung oleh proposal yang tepat guna, kesungguhan ITS membantu adalah paduan yang benar. Perajin adalah orang-orang pedesaan yang tidak punya apa-apa, harta sederhana, kekayaan terbatas, pengetahuan rendah, keberanian untuk mencari bantuan tidak ada. Apabila kita yang menjadi kepanjangan negeri ini untuk membantu desa dengan dana Abdimas, mengabaikannya, para perajin akan berusaha dengan caranya sendiri yakni mencari penghidupan 
sebagai TKW atau Pembantu Rumah Tangga. Tinggal kita lega, bahagia atau terenyuh untuk sigap konsisten dan kosekwen (sebagai kepanjangan pemerintah negeri ini) memperbaiki kehidupan mereka.

\section{DAFTAR PUSTAKA}

Christy, G and Pearce, S. (1992). Step by step art school, CERAMICS, by Hamlin an imprint of Reed. Lodon: Consumer Books Limited Michelin House,

Clark, K. (1983). The Potter's Manual, Little, Brown and Company. London: Great Dover Street. Kenny, J. B. (1949). TheComplete Book of POTTERY MAKING. Philadelphia New York: Chilton Company- Book Division.

Rhodes, D. (1957). Clay and Glazes for the Potter. New York.: Greenberg Publisher,.

Ror, Vincent, A. (1959). CERAMIC, An Illustrated Guide to Creating and Enjoying Pottery. New York.: McGraw-Hill Book Company, Inc,.

Roy. (1959). Ceramic, An Illustrated Guide to Creating and Enjoying Pottery. New York.: McGRAW-HILL BOOK COMPANY,INC.

\section{LAMPIRAN}

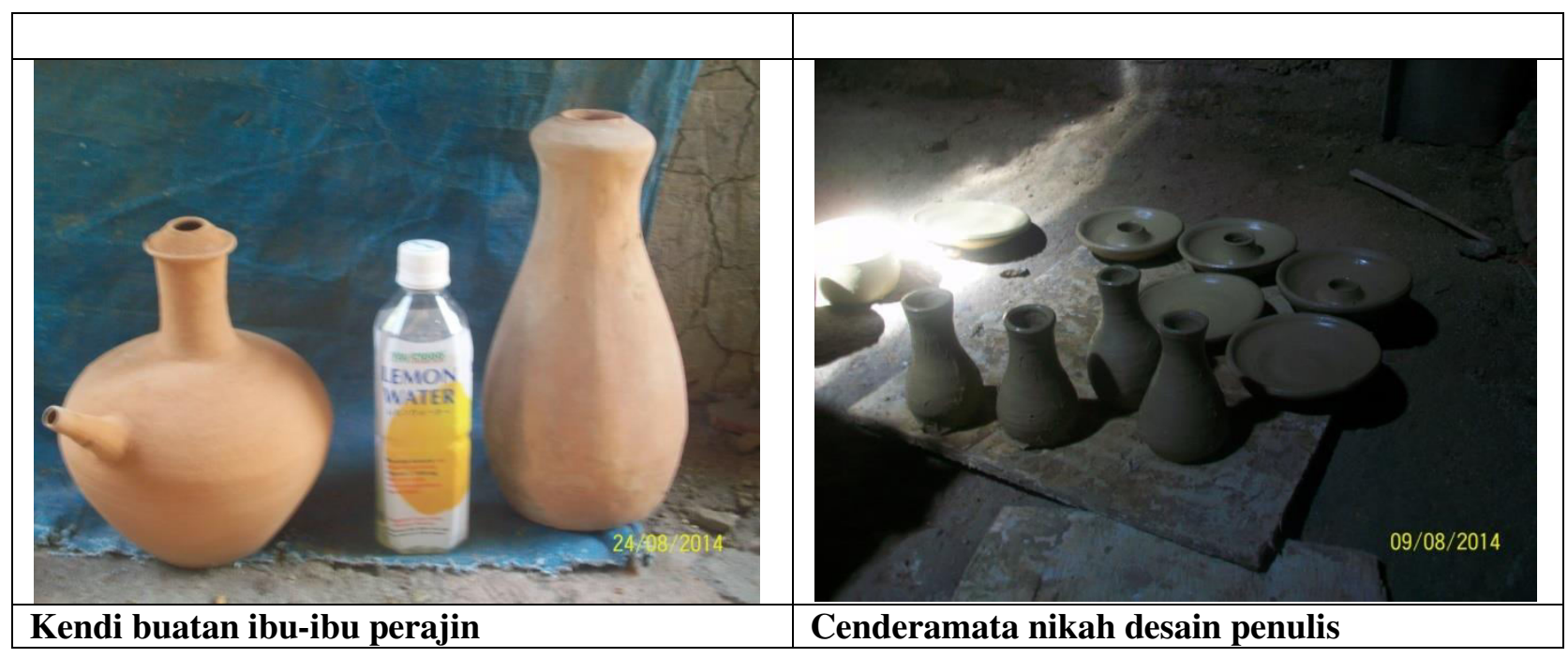



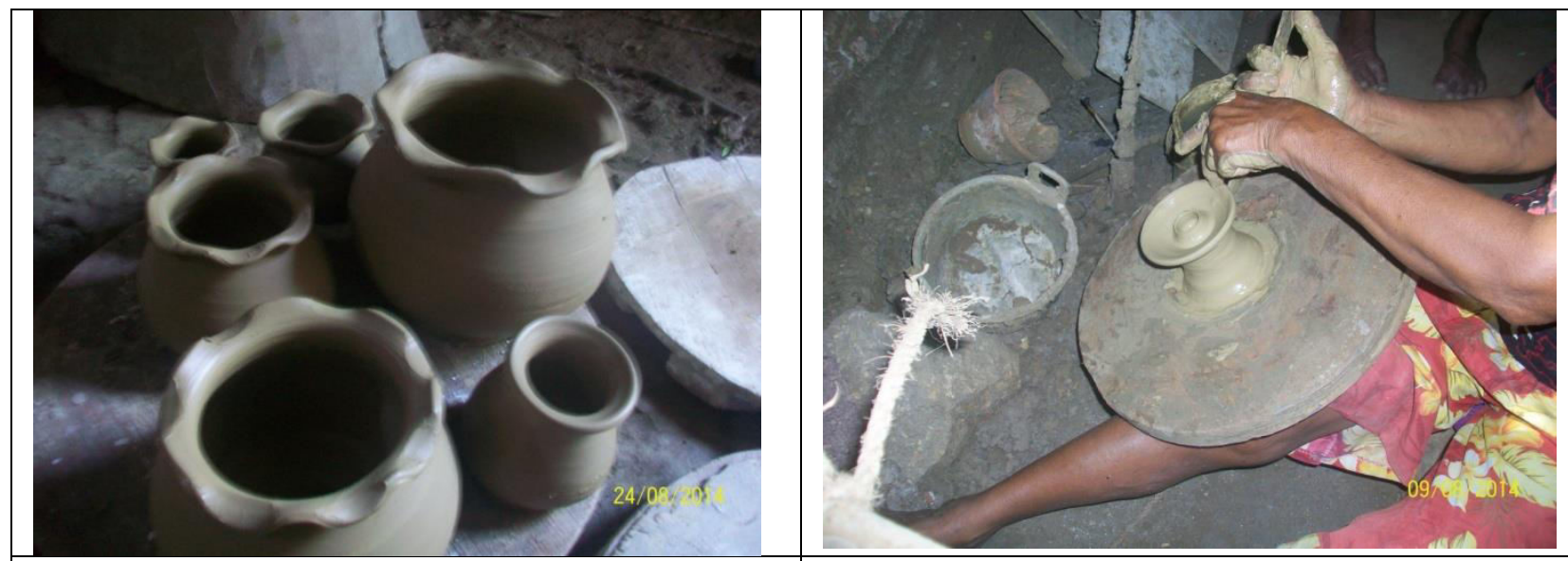

\section{Bentuk desain lainnya; pot-vas bunga meja}

Ibu perajin membuat dengan alat yang unik

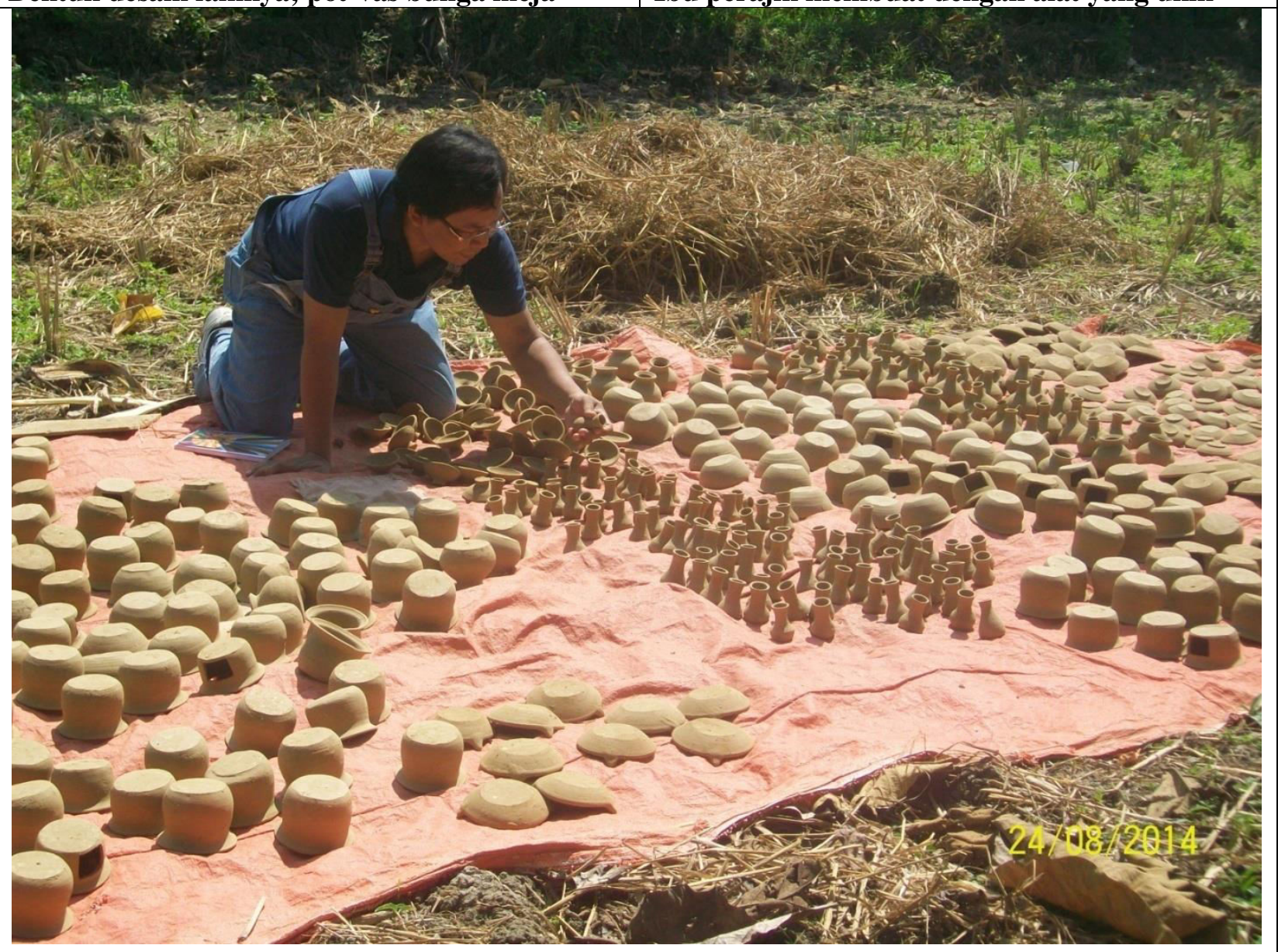

Penulis mengamati gerabah hasil buatan ibu-ibu yang dijemur, selangkah akan di bakar 


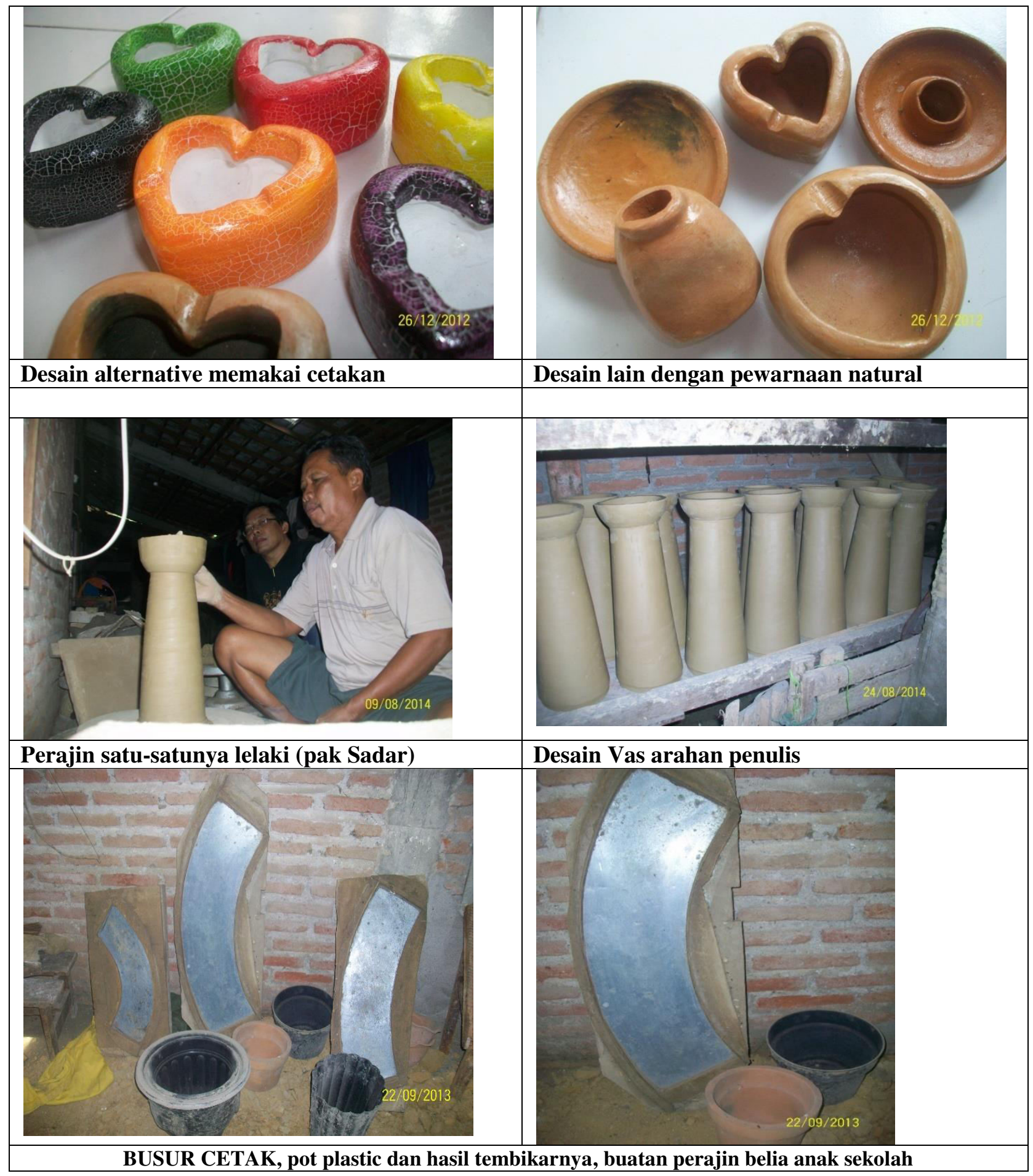




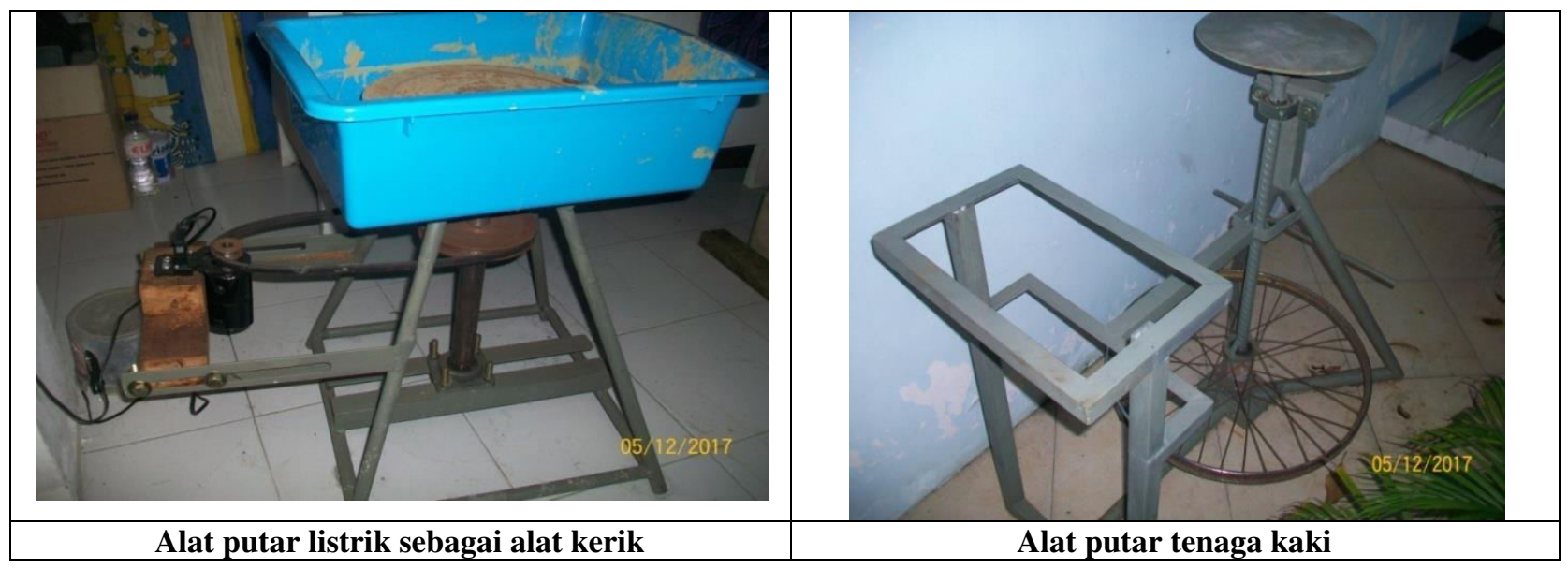

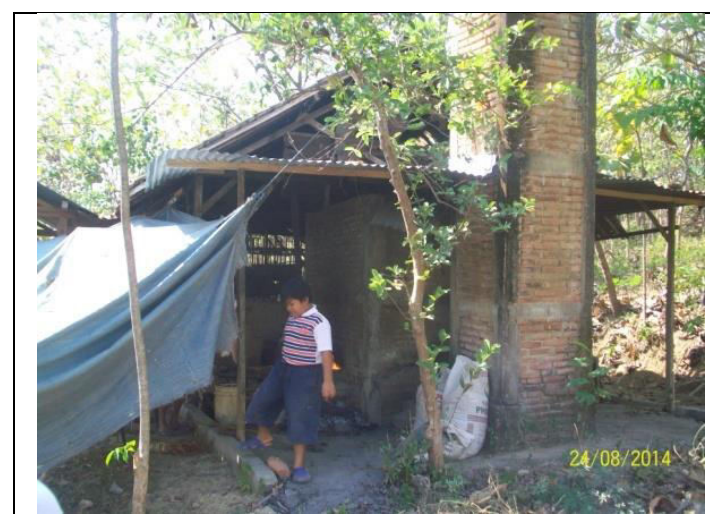

Area tungku desain penulis 1 meter kubik dengan cerobong 7 meter, dengan bahan bakar minyak tanah, kayu bakar, suatu saat di coba gas LPG

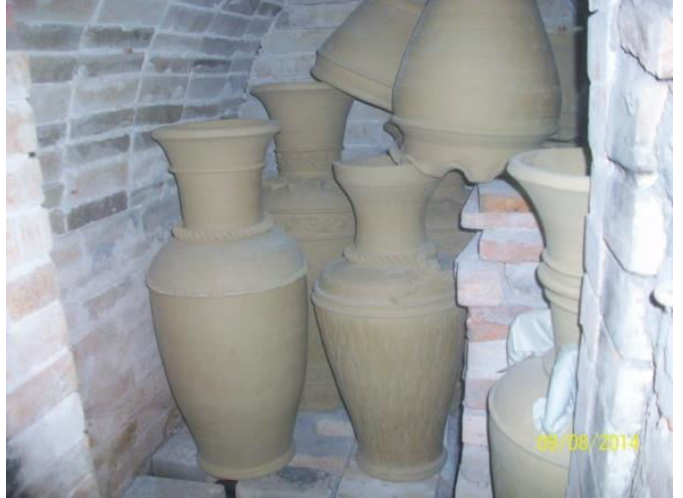

Ruang pembakaran tungku, gerabah buatan pak Sadar berukuran besar. 